Composites

Research
Vol. 26, No. 6, 343-348 (2013)

DOI: http://dx.doi.org/10.7234/composres.2013.26.6.343

ISSN 2288-2103(Print), ISSN 2288-2111(Online)

$\underline{\text { Paper }}$

\title{
발포 $\mathrm{EPP} / \mathrm{EPS}$ 의 충격특성에 관한 실험적 연구
}

\author{
김한국* · 김병준* · 정광영* · 전성식**
}

\section{Experimental Study for the Impact Characteristics of Expanded EPP/EPS Foams}

\author{
Han-Kook Kim*, Byeoung-Jun Kim*, Kwang-Young Jeong*, Seong S. Cheon*广
}

\begin{abstract}
In the present study, quasi-static tests and impact tests were performed for investigating the mechanical behaviour of EPP (Expanded polypropylene) and EPS (Expanded polystyrene). Four different density cylindrical type specimens were prepared for EPP and EPS and $0.001 \mathrm{~s}^{-1}$ and $0.1 \mathrm{~s}^{-1}$ of strain rate conditions for quasi-static tests and $100 \mathrm{~J}, 200 \mathrm{~J}$ and $300 \mathrm{~J}$ of incident energy conditions for the instrumented impact tests were considered.

초 록: 본 연구에서는 발포 폴리프로필렌(Expanded polypropylene)과 발포 폴리스티렌(Expanded polystyrene)의 준 정적 시험(Quasi-static test) 및 계장화 충격 시험(Instrumented impact test)을 수행하였다. EPP와 EPS는 4가지의 다 른 밀도에 대해 원통형 시편이 준비되었다. 준정적 시험에는 MTS 858을 사용하여 $0.001 \mathrm{~s}^{-1}$ 과 $0.1 \mathrm{~s}^{-1}$ 두 가지 변형 률속도 조건으로 진행되어 결과를 분석하였다. 계장화 충격 시험에서는 Instron dynatup $9250 \mathrm{HV}$ 를 사용하여, 각 각 $100 \mathrm{~J}, 200 \mathrm{~J}, 300 \mathrm{~J}$ 의 서로 다른 충격에너지를 가했을 때의 응력-변형률 선도 결과를 비교 분석하였다.
\end{abstract}

Key Words: 발포 폴리스티렌(expanded polystyrene), 발포 폴리프로필렌(expanded polypropylene), 충격시험(impact test), 준정적 시험(quasi-static test)

\section{1. 서 론}

예로부터 널리 사용해온 목재, 가죽, 섬유 등은 대부분 고 분자 물질임과 동시에 다공질 물질이었다. 인공적으로 만 들어진 최초의 발포체는 독일의 Hans Pfleumer에 의한 천 연고무 라텍스 폼이었으며, 이후 합성고무 라텍스 등이 발 포체의 원료로 응용되었다. 제2차 세계대전을 거치면서 $\mathrm{PE}$ (Polyethylene), PP(Polyp ropylene), PVC(Polyvinyl Chloride), $\mathrm{PU}$ (Poly urethane)와 같은 탄성이 있는 고분자가 등장하였 다[1]. 다공성 재료는 충격 시 에너지 흡수, 전자기차폐, 흡 음 및 소음 진동 방지 등의 목적으로 자동차, 전자제품 등 여러 분야에서 응용되고 있다. 현재 다공성 재료는 크게 금
속형과 고분자계로 나눌 수 있으며, 고분자계 다공성 재료 는 주로 반응사출성형(RIM, Reaction Injection Moulding)으 로 제조되고 있다[2]. 최근에는 발포기술의 발전과 함께 $\mathrm{EPP}($ Expanded polypropylene) 및 EPS(Expanded polystyrene) 에 대한 사용이 증대되면서 자동차 범퍼를 구성하는 부품 은 철강재료 대신 플라스틱 또는 비철재료로 대체 되어가 고 있는 추세이다[3,4].

$\mathrm{EPP}$ 는 비드폼이면서, 내충격성 및 내구성이 우수한 것으 로 알려져 있다[5].

EPS는 범용플라스틱의 일종인 PS(Polystyrene)에 포함되 며 낮은 열전도율 때문에 단열재로 사용되기도 하면서 외 부 충격에 완충 효과가 우수하다. 또한 발포 고분자 중에서 
밀도가 가장 낮고, 재사용이 가능하여, 전자제품 및 기타 제 품의 포장재로도 많이 사용되고 있다[6]. EPP나 EPS에 대 한 사용이 증대되면서, 재질의 고속 변형특성을 파악할 필 요가 있다. Choi 등[7]은 $50 \mathrm{~s}^{-1}$ 및 $100 \mathrm{~s}^{-1}$ 의 변형률속도에서 $\mathrm{EPP}$ 의 압축시험을 수행하고, 응력-변형률 선도를 구하였 다. Kim 등 [8]은 자동차용 인스투르먼트 패널(Instrument panel)에 사용되는 폴리프로필렌(Polypropylene) 복합재의 온도와 변형률 속도에 따른 인장시험 결과를 제시 하였으 며, Kang 등[6]은 변형률속도가 $0.06 \mathrm{~s}^{-1}$ 에서 $60 \mathrm{~s}^{-1}$ 의 구간 내 에서 EPS의 강도를 관찰하였으며, 변형률 속도에 따라 강 도가 증가하는 것을 규명하였다. Bouuix 등[9-12]은 소재의 고속변형특성을 연구하기 위하여 홉킨스 바 시험기 및 중 고속 인장 시험기를 개발하여 자동차용 강판의 변형률속 도 효과를 시험적으로 구하여 충돌해석의 기본 입력 데이 터로 활용될 수 있도록 하였다.

이와 같이 EPP 및 EPS에 대한 실험적 규명이 광범위하게 이루어졌으나, 구성방정식에 대한 내용은 찾아보기 어려웠 다. EPP 및 EPS의 거동을 전문적으로 분석하기 위해서는 유 한요소해석이 필요하며, 이를 위해서는 구성 방정식이 정 의되어야 한다. 따라서, 본 연구에서는 $\operatorname{EPP}(($ 주)엠피아이 씨) 및 $\mathrm{EPS}$ (부광스치로폴)의 구성방정식 결정을 위한 체계 적인 $\mathrm{DB}$ 를 구축하는 것을 목표로 하였다. 이를 위하여 각 발포고분자에 대해 4 가지의 다른 밀도를 갖는 원통형 시편 을 준비하였고, 준정적 압축 시험 및 충격 압축시험을 수행 하였다. $0.001 \mathrm{~s}^{-1}$ 와 $0.1 \mathrm{~s}^{-1}$ 의 변형률속도 하에서 준정적 시험 을 수행하였다[13,14]. 또한, $100 \mathrm{~J}, 200 \mathrm{~J}$ 및 $300 \mathrm{~J}$ 의 에너지를 가하는 충격시험을 수행하여, 각 재질의 4 가지 밀도에 대 한 충격에너지 흡수 및 충격 변형거동을 고찰하였다.

\section{2. 준정적 시험}

본 연구에서 사용된 EPP와 EPS는 Table 1에서 보이는 바 와 같이 각각 4종류의 다른 밀도를 갖는 재질이 준비되었 다. 또한 시편형상은 압축변형이 가급적 단순하게 1 차원이 될 수 있도록, Fig. 1에서 보이는 바와 같이 원기둥형으로 준

Table 1. Density of the EPP and EPS

\begin{tabular}{c|c|c|c|c}
\hline ID & $\begin{array}{c}\text { Diameter } \\
(\mathrm{mm})\end{array}$ & $\begin{array}{c}\text { Length } \\
(\mathrm{mm})\end{array}$ & $\begin{array}{c}\text { Density } \\
\left(\mathrm{kg} / \mathrm{m}^{3}\right)\end{array}$ & $\begin{array}{c}\text { Standard } \\
\text { deviation }\left(\mathrm{kg} / \mathrm{m}^{3}\right)\end{array}$ \\
\hline EPP_1 & 49 & 50 & 23 & 0.52 \\
\hline EPP_2 & 49 & 48 & 28 & 0.55 \\
\hline EPP_3 & 49 & 50 & 61 & 0.44 \\
\hline EPP_4 & 49 & 51 & 146 & 5.02 \\
\hline EPS_1 & 49 & 49 & 13 & 0.26 \\
\hline EPS_2 & 49 & 49 & 18 & 0.25 \\
\hline EPS_3 & 49 & 50 & 20 & 0.30 \\
\hline EPS_4 & 49 & 50 & 27 & 0.42 \\
\hline
\end{tabular}

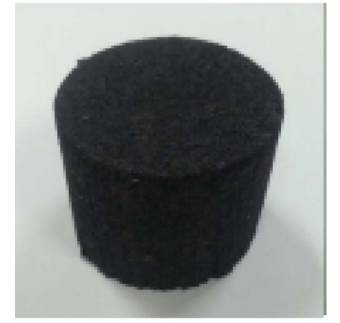

(a)

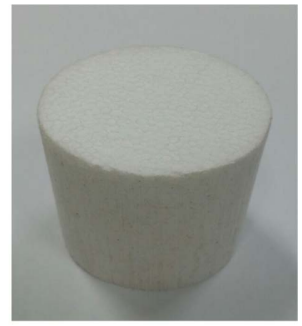

(b)
Fig. 1. Foam specimen: (a) EPP, (b) EPS

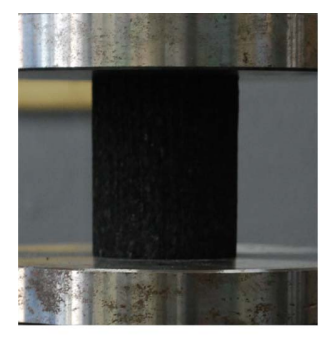

(a)

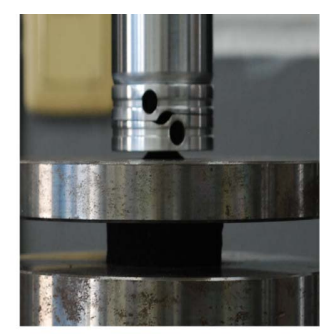

(b)
Fig. 2. Quasi-static test (EPP_4)

비하였다. 시험편의 치수는 최대 $2 \%$ 이내의 오차 내에서 가 공되었다. 각각의 시편에 대해 10 개를 선별하여 치수와 밀 도를 측정하였다. 본 연구에서 사용된 시험편은 10 개 가운 데 측정된 평균밀도와 유사한 시험편을 각각 3 개씩 선별하 여, 같은 시험에 대해 3 번의 시험이 수행될 수 있도록 하였 다. 다만, EPP_4의 경우, 재료의 높은 밀도로 말미암아, 시 편의 밀도 표준편차가 상대적으로 가장 고르지 못하게 제 조된 것을 볼 수 있었다.

준정적 시험은 향후, 구성방정식[13]을 결정하기 위하여, 두가지 변형률 속도인 $0.001 \mathrm{~s}^{-1}$ 와 $0.1 \mathrm{~s}^{-1}$ 에 대해 MTS 858을 이용하여 상온에서 진행되었다. 최대 변형량은 고밀도화 (Densification)을 고려하여, 시편의 $80 \%$ 정도까지, 즉, 현재 시편크기로 $40 \mathrm{~mm}$ 를 압축하도록 시험조건을 결정하였다.

Fig. 2는 EPP_4에 대하여 준정적 시험 중 초기 및 최대 압 축시 모습을 보여주고 있다.

같은 밀도의 시편 3 종은 모두 허용오차 내에서 거의 유 사한 응력-변형률을 보여주었고, Fig. 3에 각각의 밀도에 따 른 대표적인 선도들이 보여지고 있다.

$\mathrm{EPP}$ 의 경우 상대적으로 EPP_3 및 4의 밀도가 높기 때문 에, 탄성구간의 영률 및 플래토 응력(Plateau stress)가 EPP_1 및 2에 비해 높은 것을 확인할 수 있었다. 시험 결과 그래프 를 토대로 $0.001 \mathrm{~s}^{-1}$ 일 때 EPP_1, 2, 3, 4의 플래토 응력은 0.04, $0.1,0.29$ 및 $1.1 \mathrm{MPa}$ 로 나타났으며, $0.1 \mathrm{~s}^{-1}$ 로 변형률 속도를 증가시켰을 경우에는 $0.05,0.13,0.38$ 및 $1.48 \mathrm{MPa}$ 을 나타내 었다. 이는 플래토 응력이 $0.001 \mathrm{~s}^{-1}$ 에 비해 $0.1 \mathrm{~s}^{-1}$ 이 평균적 으로 약 $30 \%$ 높은 것을 볼 수 있었다. 


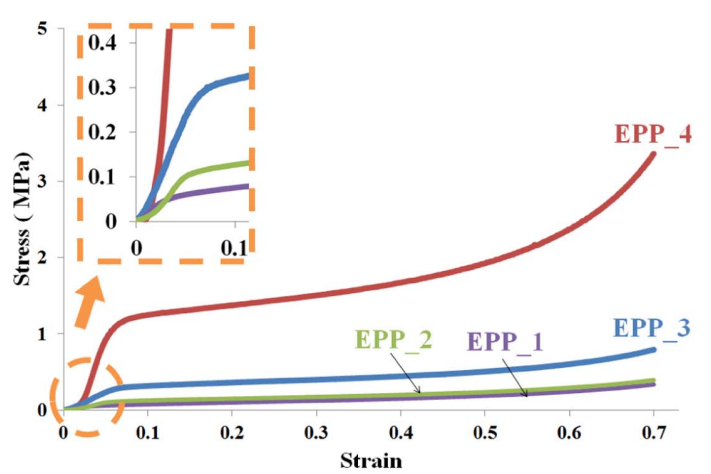

(a)

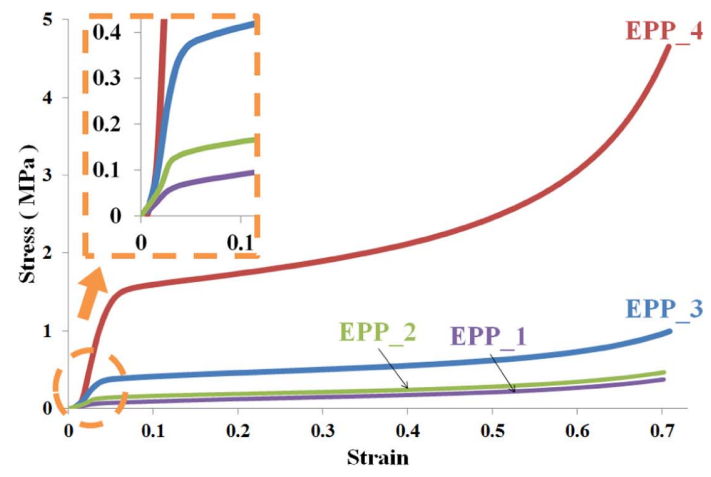

(b)

Fig. 3. Stress-strain curves under quasi-static test of EPP: (a) $0.001 \mathrm{~s}^{-1},(\mathrm{~b}) 0.1 \mathrm{~s}^{-1}$

Table 2. Measured Young's modulus of the EPP

\begin{tabular}{c|c|c}
\hline \multirow{2}{*}{ ID } & Strain rate $\left(\mathrm{s}^{-1}\right)$ & $\begin{array}{c}\text { Measured Young's } \\
\text { modulus }(\mathrm{MPa})\end{array}$ \\
\cline { 1 - 1 } EPP_1 & \multirow{3}{*}{0.001} & 2.01 \\
\cline { 1 - 1 } & & 2.40 \\
\cline { 1 - 1 } EPP_2 & & 5.06 \\
\cline { 1 - 1 } EPP_3 & & 34.91 \\
\hline EPP_4 & \multirow{2}{*}{0.1} & 2.34 \\
\hline EPP_1 & & 5.54 \\
\cline { 1 - 1 } & & 14.48 \\
\cline { 1 - 1 } EPP_2 & & 45.77 \\
\hline EPP_3 & &
\end{tabular}

Fig. 3에서 왼쪽 상단의 확대그림은 밀도에 따른 탄성계 수를 비교하기 위해서 첨부되었다. Table 2는 변형률 속도 에 따른 EPP의 탄성계수를 보여주고 있다. 탄성계수는 밀 도가 높아질수록 증가하며, 변형률 속도가 증가할수록 증 가하는 것을 확인할 수 있었다. Fig. 4는 EPS의 준정적 시험 결과 그래프를 보여주고 있다.

EPS의 경우 밀도에 따라 플래토 응력이 분포된 것을 볼 수 있었다. $0.001 \mathrm{~s}^{-1}$ 일 때 EPS_1, 2, 3 및 4의 플래토 응력은 $0.04,0.08,0.1$ 및 $0.15 \mathrm{MPa}$ 을 나타내었는데, $0.1 \mathrm{~s}^{-1}$ 로 변형률

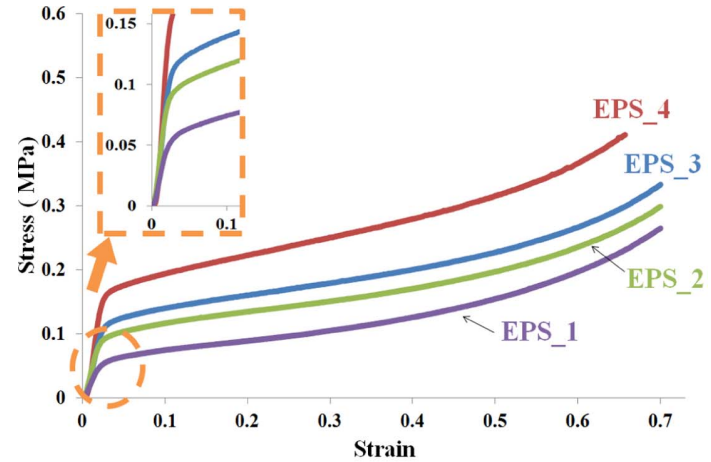

(a)

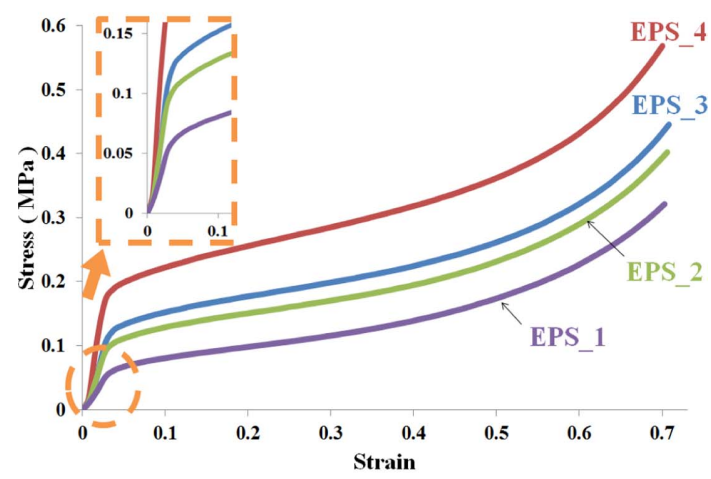

(b)

Fig. 4. Stress-strain curves under quasi-static test of EPS: (a) $0.001 \mathrm{~s}^{-1}$, (b) $0.1 \mathrm{~s}^{-1}$

Table 3. Measured Young's modulus of the EPS

\begin{tabular}{c|c|c}
\hline \multirow{2}{*}{ ID } & Strain rate $\left(\mathrm{s}^{-1}\right)$ & $\begin{array}{c}\text { Measured Young's } \\
\text { modulus }(\mathrm{MPa})\end{array}$ \\
\cline { 1 - 1 } EPS_1 & \multirow{3}{*}{0.001} & 3.38 \\
\cline { 1 - 1 } & & 5.67 \\
\cline { 1 - 1 } & & 6.34 \\
\cline { 1 - 1 } & & 10.55 \\
\hline EPS_2 & \multirow{3}{*}{0.1} & 2.21 \\
\hline EPS_4 & & 3.84 \\
\hline EPS_1 & & 5.32 \\
\hline EPS_2 & & 8.92 \\
\hline EPS_3 & &
\end{tabular}

속도를 증가시켰을 경우 $0.06,0.1,0.12$ 및 $0.18 \mathrm{MPa}$ 을 나타 내었다. 이는 플래토 응력이 $0.001 \mathrm{~s}^{-1}$ 에 비해 $0.1 \mathrm{~s}^{-1}$ 이 평균 적으로 약 $20 \%$ 정도 높게 나타났다. 또한 준정적 시험결과 로부터, 밀도가 높을수록 발포고분자의 탄성구간 기울기가 높고, 플래토 응력도 높아지는 것을 확인하였다. Table 3은 변형률 속도에 따른 EPS의 탄성계수를 나타내었다. EPS의 경우, 변형률 속도가 높아짐에 따라, 탄성계수가 낮아지는 것을 볼 수 있었는데, 이는 향후 좀더 실험 등을 통하여 확 
인이 필요할 것으로 여겨지고 있다.

\section{3. 충격 시험}

시험편은 준정적 시험에 사용된 시편과 같은 형상 및 재 질의 시편을 준비하였다. 시험은 3 종류의 충격에너지 수준 을 갖도록 $100 \mathrm{~J}, 200 \mathrm{~J}, 300 \mathrm{~J}$ 을 선택하였다. 이에 따라, 충격 체의 질량은 $26.4 \mathrm{~kg}$ 이 사용되었고, 각각 충격체의 속도는 $100 \mathrm{~J}$ 의 경우 $2.5 \mathrm{~m} / \mathrm{s}, 200 \mathrm{~J}$ 의 경우 $3.7 \mathrm{~m} / \mathrm{s}, 300 \mathrm{~J}$ 의 경우 $4.7 \mathrm{~m} / \mathrm{s}$ 로 맞추었다. Fig. 5는 고속카메라를 이용해 시간별 시험편의 충격시험 과정을 보여주고 있다.

본 연구에서는 ODS(Onset of densification strain)의 결정 을 위해서 접선을 그어 접선의 교차점을 선택하는 방법을 택하였다[15,16]. 그러나 접선을 긋는 방법이 연구자에 따

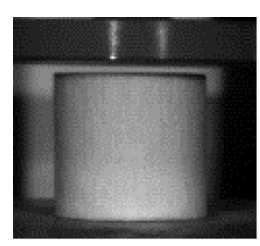

Os

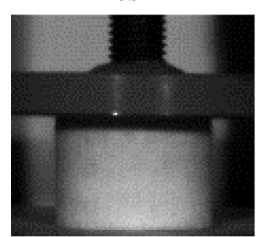

$0.0050 \mathrm{~s}$

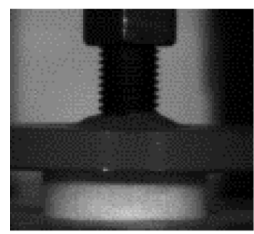

0.0110s

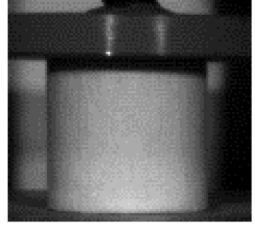

0.0010s

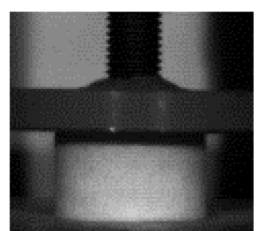

$0.0070 s$

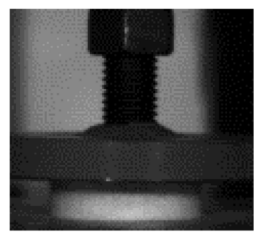

0.0130s

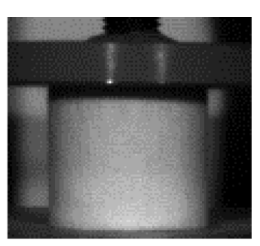

$0.0020 \mathrm{~s}$

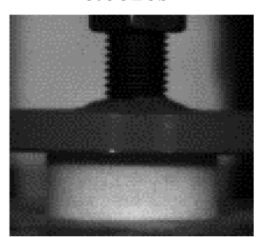

$0.0090 s$

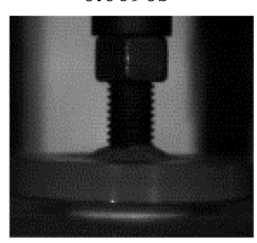

$0.0150 s$
Fig. 5. High speed camera images of impact test (EPS_1)

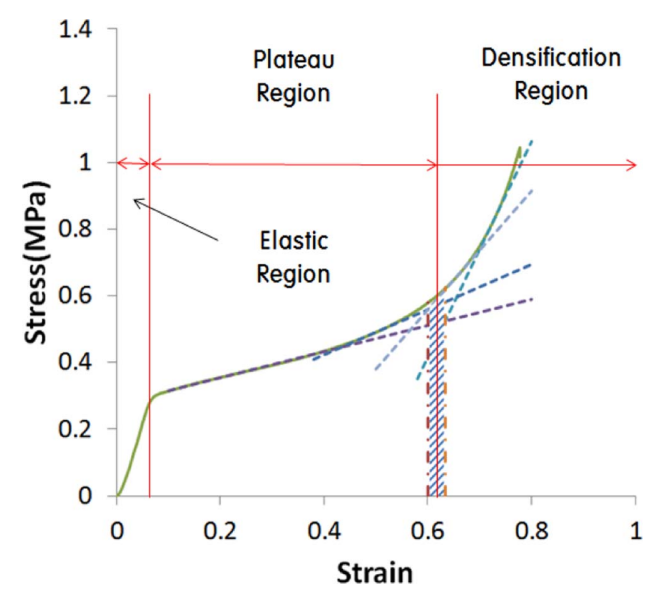

Fig. 6. Determination of ODS

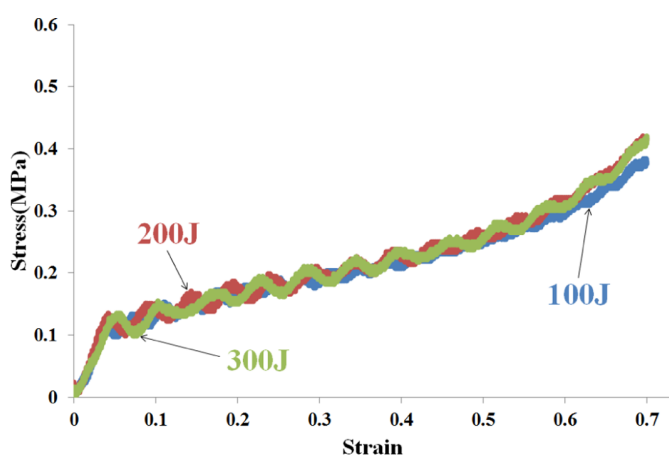

(a)

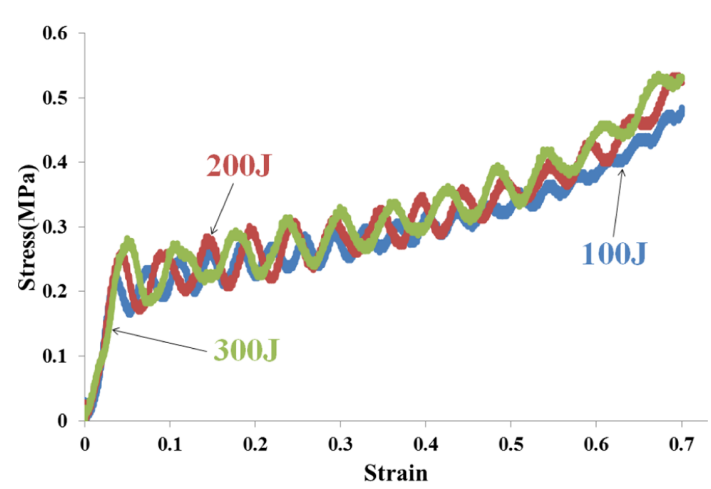

(b)

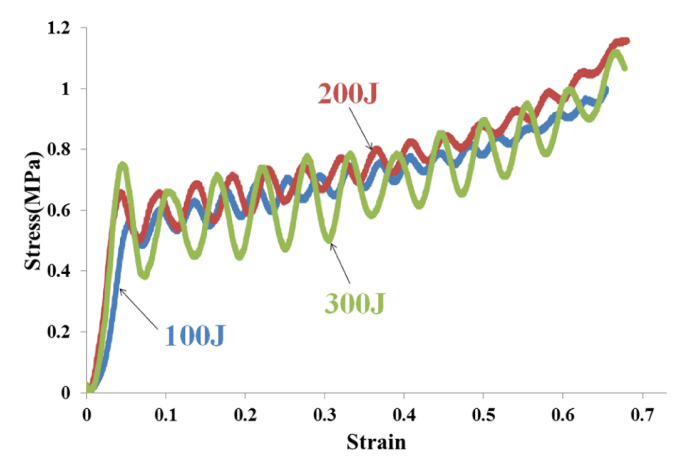

(c)

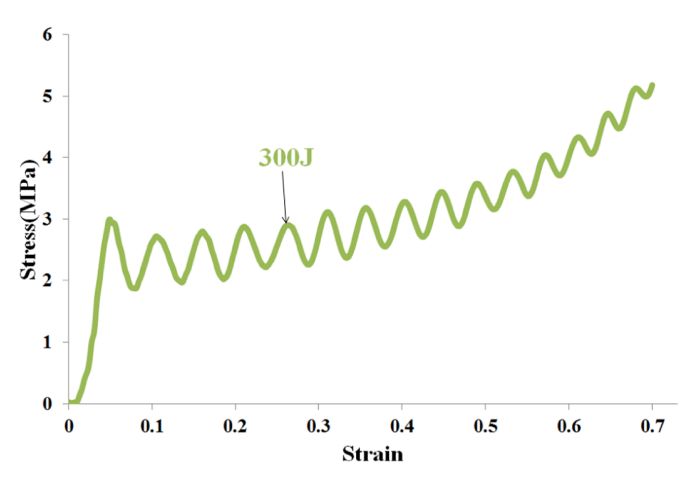

(d)

Fig. 7. Stress-strain curves under impact test: (a) EPP_1, (b) EPP_2, (c) EPP_3 and (d) EPP_4 


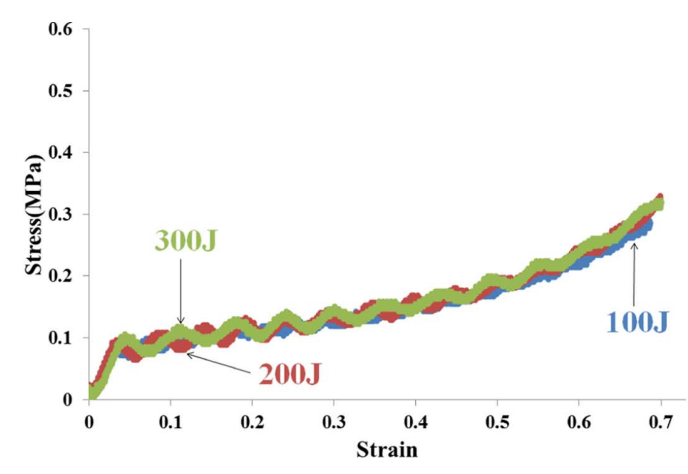

(a)

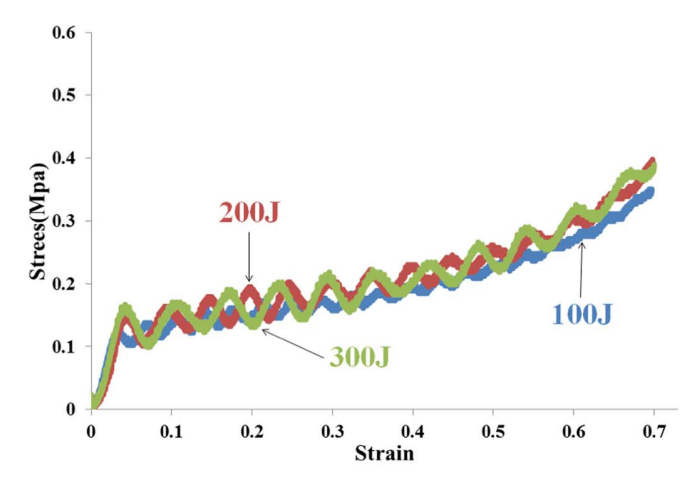

(b)

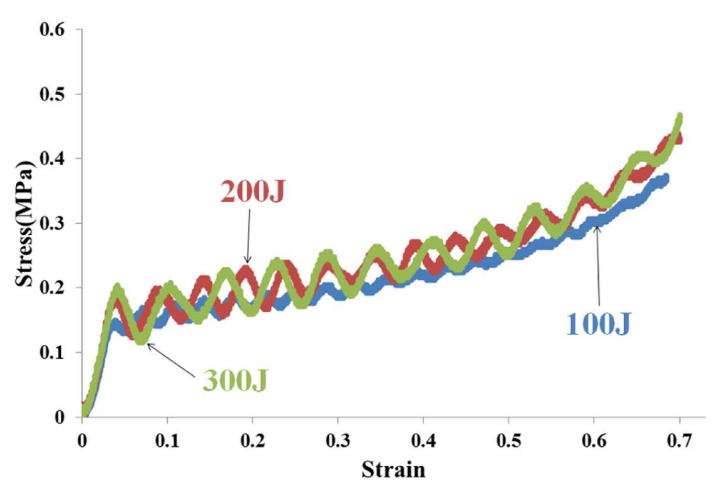

(c)

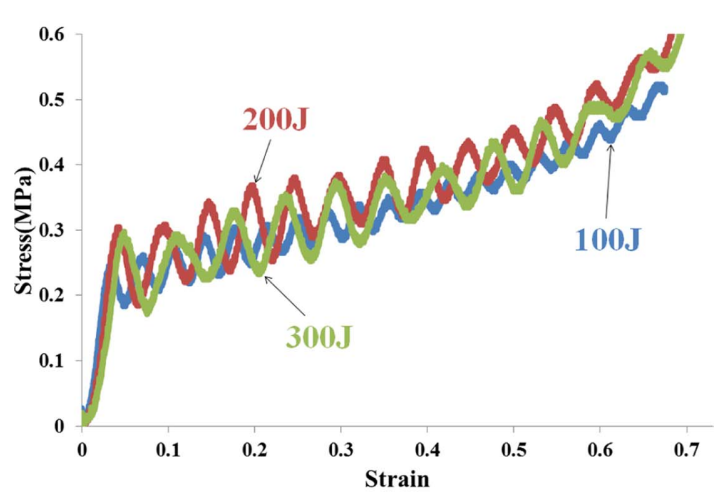

(d)

Fig. 8. Stress-strain curves under impact test: (a) EPS_1, (b) EPS_2, (c) EPS_3 and (d) EPS_4
라 달라질 수 있으며, 이에 따라 같은 결과에 대해서도 다 른 ODS를 선택할 가능성이 있다. 따라서 상대적으로 객관 적인 ODS 값을 선택하기 위해 Fig. 6과 같이 최대 및 최소 값을 찾아 평균을 선택하였다.

각각의 ID에 따라, 3 개의 시편에 대해 충격시험을 수행 하여, 결과의 편차가 크지 않은 것을 확인하였고, 그중 대 표적인 것을 골라서, 응력-변형률 선도를 고찰하였다. Fig. 7은 충격시험으로부터 얻은 EPP들의 응력-변형률선도를 나타내었다. 참고로, 저역통과 필터(Low pass filter) 등으로 고주파 영역을 없애면, 오실레이션이 제거된 커브를 얻을 수 있다[17].

EPP_4는 상대적으로 높은 밀도 때문에, 초기 충격에너지 가 $100 \mathrm{~J}$ 및 $200 \mathrm{~J}$ 일 때는 시편을 파단시킬 수 없어서, 플래 토 및 고밀도화 구간을 관측할 수 없었다. 따라서, $100 \mathrm{~J}$ 및 $200 \mathrm{~J}$ 일 때 그래프는 Fig. 7의 (d)에 첨부되지 않았다.

시험 결과와 같이 충격 에너지가 변하더라도 일정한 탄 성, 플래토 및 고밀도화 구간을 나타내는 것을 확인하였다.

동일 조건의 시험편에 대해 충격에너지 크기에 따라 얻 어진 충격시험결과를 비교한 결과 충격에너지의 증가에 따 라 플래토 응력이 EPP_1, 2, 3 모두 약 $10 \%$ 씩 증가함을 보 였다. 이는 밀도의 증가에 따라 충격 흡수량이 점차 증가한 다는 것으로 볼 수 있다.

Fig. 8은 EPS의 충격특성에 대한 응력-변형률 선도를 나 타내었다. Fig. 8도 역시 EPS의 밀도가 증가함에 따라 충격 에너지 흡수량도 증가함을 보여주고 있다. 밀도차가 크지 않은 EPS_2와 EPS_3의 경우, 그래프가 유사하게 나타난 것 을 볼 수 있었다. EPS 모두 $100 \mathrm{~J}$ 과 $200 \mathrm{~J}$ 의 플래토 응력은 약 $10 \%$ 차이가 나는 것을 확인하였다.

\section{4. 결 론}

본 연구에서는 $\mathrm{EPP}$ 및 $\mathrm{EPS}$ 의 준정적 및 충격 압축 특성 을 파악하고, 이를 $\mathrm{DB}$ 화하여, 향후 구성 방정식을 정의하 기 위한 준정적 시험 및 충격시험이 수행되었다. 이를 위 하여 EPP 및 EPS에 대해 4가지의 다른 밀도를 갖는 원통 형 시편을 준비하였고, 준정적 압축 시험 및 충격 압축시 험을 수행하고 변형거동을 파악하여 다음과 같은 결론을 얻었다.

1) 준정적 시험결과, EPP나 EPS 모두 밀도가 높을수록 플래토 응력도 높고, 에너지 흡수도 높은 것을 확인하였다.

2) 변형률 속도가 $0.001 \mathrm{~s}^{-1}$ 에서 $0.1 \mathrm{~s}^{-1}$ 로 증가하는 동안, $\mathrm{EPP}$ 는 약 $30 \%, \mathrm{EPS}$ 는 약 $20 \%$ 정도의 플래토 응력이 증가하는 것을 볼 수 있었다.

3) 충격시험을 통하여, EPP 및 EPS는 밀도가 증가함에 따 라 충격 에너지 흡수량도 증가함을 보여주고 있다. 플래토 응력의 경우, 밀도가 증가함에 따라, 약 플래토 응력이 약 $10 \%$ 씩 증가되는 것을 볼 수 있었다. 


\section{후 기}

이 논문은 2012년도 정부(교육과학 기술부)의 재원으로 한국연구재단의 지원을 받아 수행된 기초연구사업임 (2012R1A1A2008823).

\section{참고문헌}

1. Cha, K.C., Song, J.S., Lee, S.M., and Mun, M.S., "Effects of Chain Extender and Inorganic Filler on the Properties of Semirigid Polyurethane Foams," Journal of the Korean Polymer, Vol. 34, No. 1, 2010, pp. 8-13.

2. Szycher, M., Szycher's Handbook of Polyurethanes Boca Raton: CRC Press, 1999.

3. Kim. M.H., Cho, S.S., and Ha, S.K., "Design and Structural Analysis of Aluminum Bumper for Automobiles," Transactions of KSAE, Vol. 7, No. 3, 1999, pp. 217-227.

4. Lee, S.J., Park, J.S., Koo, D.H., and Jung, B.H., "The Development of Material Technology Applied to Bumper Beam," Transactions of KSAE, Vol. 10, No. 4, 2002, pp. 206-215.

5. Choi, C.H., "Expanded Polypropylene and Packaging Materials," Journal of the Monthly Packaging World, No. 214, 1996, pp. 5867.

6. Kang, W.J., Cheon, S.S., Lee, I.H., Choi, S.U., Min, J.H., Lee, S.H., and Bea, B.K., "Investigation of the Strain Rate Effects of EPS Foam," The Journal of the Korean Society for Composite Materials, Vol. 23, No. 1, 2010, pp. 64-68.

7. Choi, K.S., Kang, W.J., Kim, K.H., and Kim, S.K., "High Strain Rate Compression Behavior of EPP Bumper Foams," Transactions of the Korean Society of Automotive Engineers, Vol. 17, No. 4, 2009, pp. 118-125.

8. Kim, J.S., Huh, H., Lee, K.W., Ha, D.Y., Yeo, T.J., and Park, S.J., "Evaluation of Dynamic Tensile Characteristics of Polypropylene with Temperature Variation," International Journal of Auto- motive Technology, Vol. 7, No. 5, 2006, pp. 571-577.

9. Bouuix, R., Voit, P., and Lataillade, J., "Polypropylene Foam Behaviour Under Dynamic Loading : Strain Rate, Density and Microstructure Effects," International Journal of Impact Engineering, Vol. 36, Issue. 2, 2009, pp. 329-342.

10. Ouellet, S., Cornin D., and Worswick, M., "Compressive Response of Polymeric Foams Under Quasi-static Medium and High Strain Rate Conditions," Polymer Testing, Vol. 25, No. 6, 2006, pp. 731-743.

11. Huh, H., Kang, W.J., and Han, S.S., "A Tension Split Hopkinsom Bar for Investigating the Dynamic Behavior of Sheet Metals," Experimental Mechanics, Vol. 42, No. 1, 2002, pp. 8-17.

12. Huh, H., Kim, S.B., Song, J.H., and Lim, J.H., "Dynamic Tensile Characteristics of TRIP-type and DP-type Steel Sheets for and Auto-body,' International Journal of Mechanical Sciences, Vol. 50, 2008, pp. 918-931.

13. Jeong, K.Y., Cheon, S.S., and Munshi, M.B., "A Constitutive Model for Polyurethane Foam with Strain Rate Sensitivity," Journal of Mechanical Science and Technology, Vol. 26, No. 7, 2012, pp. 2033-2038.

14. Jeong, K.Y., Kim, B.J., and Cheon, S.S., "A Constitutive Equation for Expanded Polypropylene Foam under Dynamic Loading," Proceeding of The Korean Society for Composite Materials, Changwon, Korea, Nov. 2013, pp. 149-150.

15. Paul, A., and Pamamurty, U., "Strain Rate Sensitivity of a Closed-cell Aluminium Foam," Materials Science and Engineering A, 2000, Vol. 281, pp. 1-7.

16. Lopatnikov, S.L., Gama, B.A., and Gillespie Jr J.W., "Modeling the Progressive Collapse Behaviour of Material Foam," International Journal of Impact Engineering, Vol. 134, 2007, pp.587595

17. Jeon, H.S., Choi, Y.C., and Park, J.W., "Measuring Structural Vibration Using Curve Fitting from Vedio Signal," Journal of the Korean Society for Noise and Vibration Engineering, Vol. 23, No. 11, 2007, pp. 99-107. 